\title{
DFES AND DWP: A SHARED EVIDENCE BASE THE ROLE OF SKILLS IN THE LABOUR MARKET
}

THIS PAPER IS A SURVEY OF EVIDENCE NOT A STATEMENT OF GOVERNMENT POLICY 
Any enquiries about this paper should be directed to:

Stephanie Bell Stephanie.bell@dfes.gsi.gov.uk or

Jacqui Hansbro jacqui.hansbro@dwp.gsi.gov.uk 


\section{DfES and DWP: A Shared Evidence Base - The Role of Skills in the Labour Market}

\section{Outline}

This paper presents a shared DfES and DWP interpretation of the evidence on the role of skills in the labour market and their impact on productivity. This represents the evidence base where our priorities overlap, the focus of this paper is therefore those with low skills - how to improve their employability for sustained employment that provides opportunities for progression. The paper is structured as follows:

- Executive Summary [page 4]

- The UK's international performance on employment and productivity [page 7]

- The role of qualifications and skills in the labour market. [page 10]

- General evidence on the link between skills and productivity. [page 15]

- Improving employment and skills levels of those with no or low qualifications or skills. [page 18]

- The future supply of, and demand for, skills. [page 32]

- Conclusion. [page 38]

- References [page 42] 


\section{Executive Summary}

\section{Context}

- Economic output and growth depends on: a) the number of people in work;

b) the number of hours worked and c) how productive they are. In international comparisons with key competitors we compare favourably on (a) and (b) and have been improving significantly over the last decade on (c).

- Skills are one of the five drivers of productivity. Skills needs of firms are increasing and are expected to increase in the future from globalisation and technological change.

- Although we expect the skills profile of the UK to continue to improve and the proportion of unqualified people to fall significantly, the UK economy is still expected to be disadvantaged by having a relatively long tail of lowqualified and low- skilled labour. This skills deficit contributes to the productivity gap with some of our key competitors.

- Therefore, in order to increase productivity, maximise output and improve social equity, we need to:

- improve the qualifications and skills of the low qualified and low skilled; and

- maintain and increase employment rates.

- There is evidence that an investment in skills can lead to increased demand for those skills, commonly called a "supply-push" mechanism. For example the decades of increase in the supply of graduates helped to stimulate demand for higher level skills, enabling the 'price' of such skills to remain at a premium. 
What does the evidence say about how to improve employment rates for those with low or no qualifications?

- A lack of qualifications can be a disadvantage in the labour market; a disadvantage often compounded by other barriers to work. We need better diagnostic tools in order to identify those unemployed and inactive people who would benefit from participation in skills training, especially those for whom upskilling is necessary to obtain good quality, sustainable employment.

- Employment focused programmes have generally had more impact on initial employment chances for the low skilled, and are typically more costeffective than education focused programmes. However, the jobs lowskilled people enter (either through employment or education focused programmes) are typically low-paid and provide few prospects for progression and training.

- Training will be necessary to help move some of the low qualified and lowskilled group into work. We need to build on and develop the best aspects of past programmes such as: developing strong links with employers; a clear work focus; use of employer placements; and support which is tailored to meet individual needs.

\section{What does the evidence say about how to improve workforce skills for those with low or no qualifications?}

- The best improvement in earnings and productivity occurs when qualifications are gained in the workplace. However, the evidence is clear that low-qualified and low-skilled people are much less likely to receive training from their employers. This presents a significant challenge for policy to address.

- Many low qualified and low skilled people are unemployed or inactive and on benefits. For this group, the evidence challenge is how best to improve their skills and qualifications in order to improve long-term employability and productivity. 
- Because of the benefits of employer provided training as shown by research on earnings and employment rates, there should be an increased emphasis for public funds on well-designed training for the low qualified who are in work and to enable the non-employed to continue their training when they move into work.

- The evidence suggests that the best approach is a combined one where people continue active job search and alongside that they undertake training that they continue if they obtain a job. 


\section{Section One: The UK's international performance on employment and}

\section{productivity}

1. An economy's output depends on three things:

a) how many people are working;

b) how many hours are worked; and

c) how productive they are.

2. The UK has a high employment rate which helps raise output. Recent data on the UK's employment rate show it was $74.6 \%$ for the three months ending May 2006, this is high by international comparisons: the UK has the highest employment rate in the G7 (Figure 1)and fourth highest in the EU25, after Denmark, the Netherlands and Sweden.

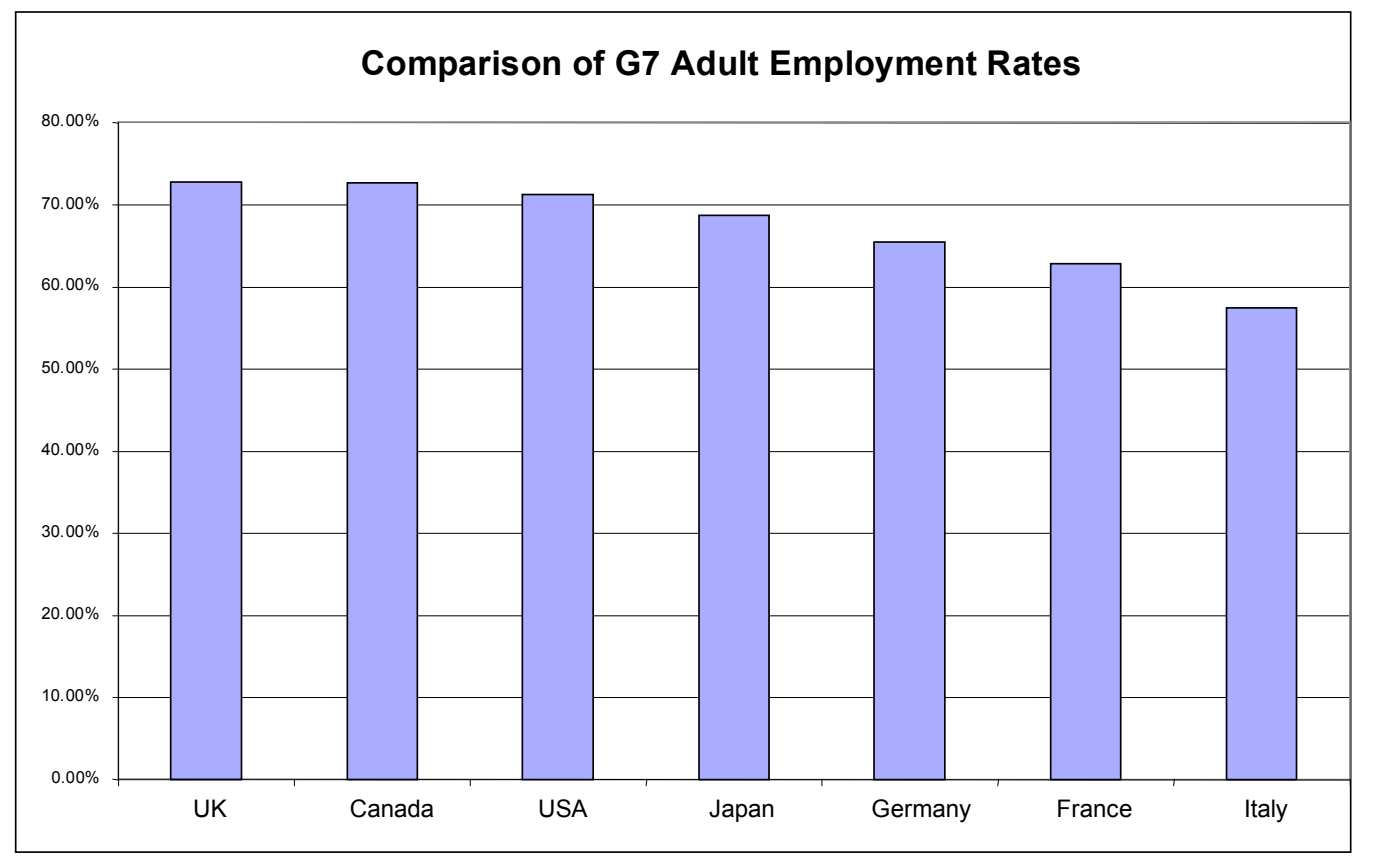

Figure 1, Notes: Figures refer to 2004 and are for all those aged 16-64 in UK and USA and all those aged 15-64 in Canada, Japan, Germany, France and Italy. Source: OECD Employment Outlook 2005. The UK employment rate was recorded to be $74.6 \%$ for the three months ending May 2006.

3. UK workers also tend to work longer hours. This combined with our high employment rate means that, in terms of output per head of population, the UK performs favourably in relation to key competitor economies across the EU. 
4. However, the UK does less well in terms of productivity. In terms of GDP per hour worked ${ }^{1}$ workers in France are $29 \%$ more productive per hour than UK workers, and workers in US and Germany $16 \%$ more productive. There has also been significant progress on this measure since 1995, reducing the gap with Germany, France and US by 10, 8 and 4 index points respectively and increasing the positive gap with Japan. Hence productivity is a key concern for the UK economy.

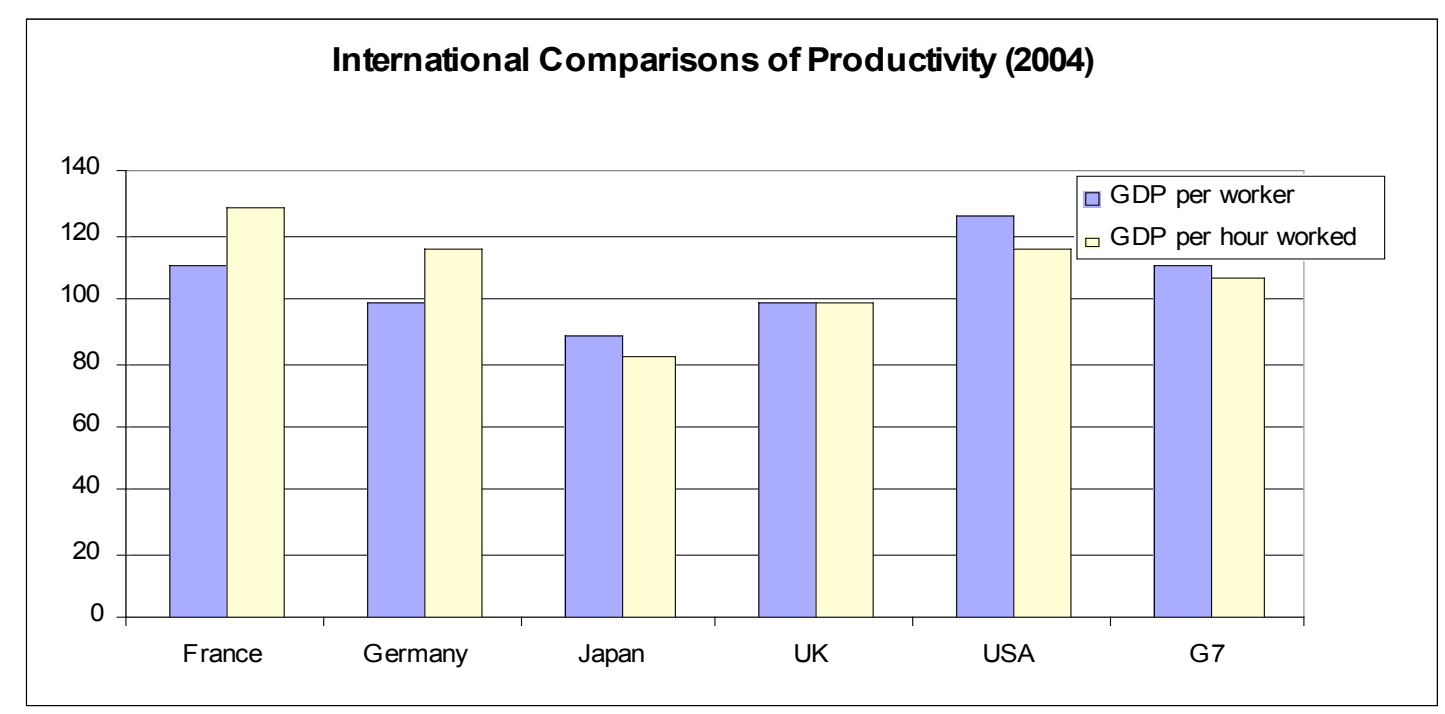

Figure 2. Source: ONS International Comparisons of Productivity (2004)

5. Skills are one of the five key drivers of productivity. ${ }^{2}$ There is evidence of complementarities between the drivers: increases in one driver may lead to increases in others. It may also be the case that overall increases are possible only with increases in a combination of the five drivers e.g. effective use of capital investment relies on workforce skills, and innovation is an expression of workforce skills.

6. There is relatively limited scope for improving economic prosperity by increasing employment rates and the number of hours worked, compared to the scope for increasing productivity of that labour. For example, in Budget

\footnotetext{
${ }^{1}$ This indicator more accurately portrays the UK productivity situation as it takes into account the number of hours worked, not just the output per worker.

${ }^{2}$ The other four are enterprise, innovation, competition and investment.
} 
2006, Treasury estimate that the trend rate of growth from 2006 onwards will be 2.5 per cent per annum. This is built up as follows:

\begin{tabular}{|l|l|l|l|l|}
\hline \multicolumn{4}{|l|}{ Annual percentage growth rate in: } \\
\hline Output & $\begin{array}{l}\text { Output per } \\
\text { hour }\end{array}$ & $\begin{array}{l}\text { Hours per } \\
\text { worker }\end{array}$ & $\begin{array}{l}\text { Employment } \\
\text { rate }\end{array}$ & $\begin{array}{l}\text { Working age } \\
\text { population }\end{array}$ \\
\hline 2.5 & 2.15 & -0.2 & 0.2 & 0.4 \\
\hline
\end{tabular}

Table 1 Source: Budget 2006

\section{Conclusion}

7. DWP and DfES recognise the importance of maximising productivity and continuing to improve employment rates, in order to compete and prosper in international terms. This will benefit not only the individual, but also the employer and the wider society through more desirable social outcomes.

8. The next two chapters unpick the role that qualification and skills have in terms of employment chances and productivity. 


\section{Section Two: The role of qualifications and skills in the labour market.}

\section{There is a wealth of evidence to suggest that skills and} qualifications are important to individuals, the economy and society.

People with skills and qualifications are more likely to be in employment, and be productive.

10. Before discussing the evidence, it is important to note that qualifications are not the same as skills. People can have skills but may not have qualifications to certify them, especially for older people. However, qualifications should certify a particular type and level of skill. But there are problems. Qualifications can be seen as a snapshot measure, certifying someone's skill level at a particular moment, although the skills may decay over time if not maintained. Qualifications also may not always reflect the skills that employers demand. Despite these problems, highest qualification is often used as a proxy for skill levels as data on them are more readily available. $^{3}$

\section{People with higher qualifications are more likely to be employed} than people with lower level or no qualifications. The employment rate for males with no qualifications is $54.7 \%$ and for males with Level 2 qualifications is $79.0 \%$. The unemployment rate is $7.6 \%$ for males with no qualifications compared to $5.0 \%$ for those with Level 2 qualifications ${ }^{4}$. For females with no qualifications the employment rate is $40.4 \%$ compared to $71.1 \%$ for those with Level 2 qualifications.

\footnotetext{
${ }^{3}$ For more details on the difference between skills and qualifications and the value of qualifications see Appendix A where this is explored in more detail.

${ }^{4}$ Data taken from LFS winter 2005.
} 
Economic Activity by Highest Qualification

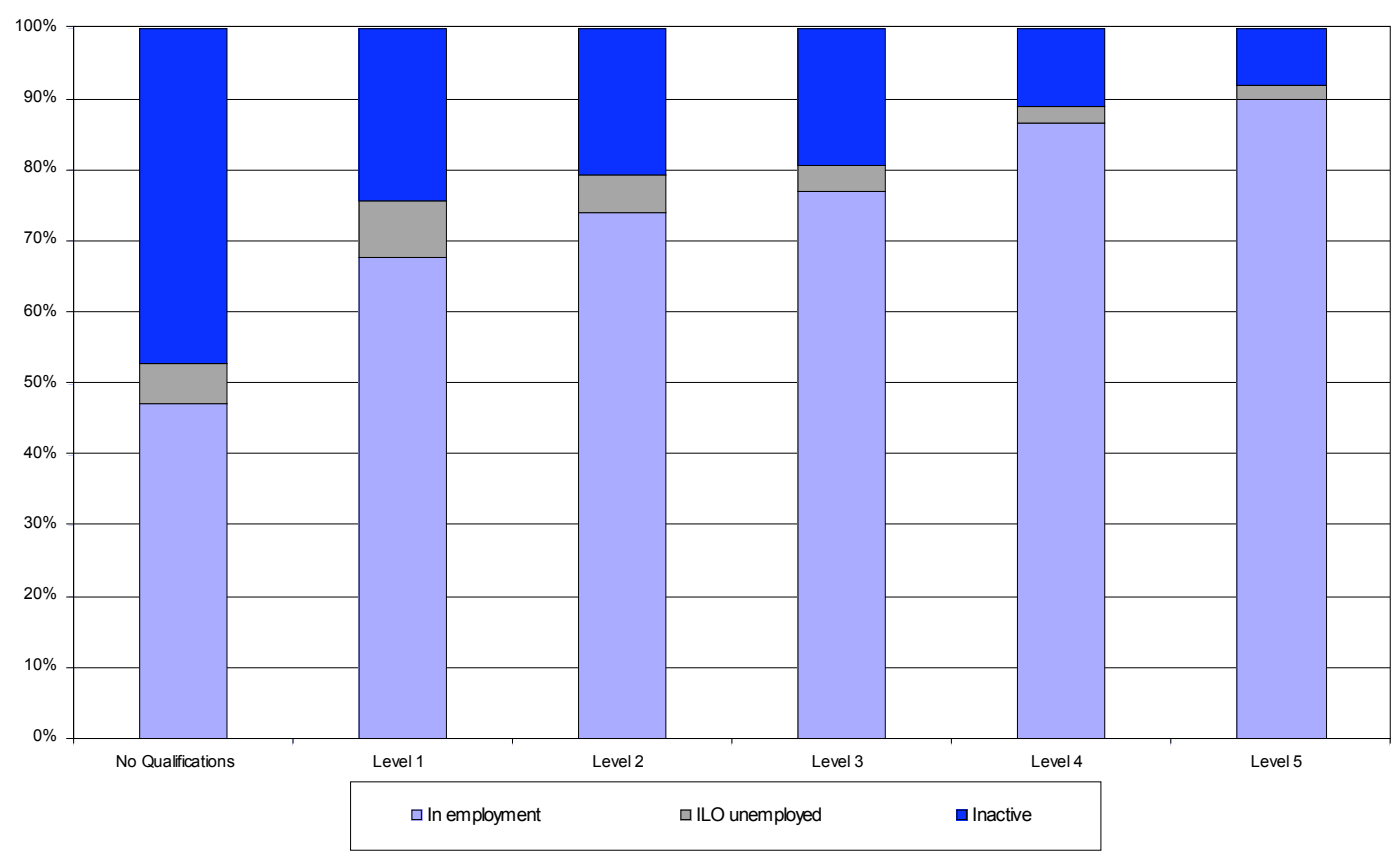

Figure 3. Source: Labour Force Survey, Spring 2006

GB activity rates for the working age population (aged 16-59/64).

12. Higher levels of literacy and numeracy skills are associated with a higher likelihood of being in work. People with better basic skills are more likely to be employed than those with poor basic skills. For example, even controlling for other characteristics (including highest qualification) those with Level 1 literacy are 6 percentage points more likely to be employed than those with Entry Level 3.

\section{Many people face multiple barriers to employment, and when an} individual faces a range of barriers to employment, having no qualifications or skills may be a contributory factor preventing them from moving into employment. For example, the employment rate for lone parents with qualifications is $63 \%$, compared with only $30 \%$ for those without qualifications. On the other hand, the employment rate for women with no qualifications but who are not lone parents is $72 \% .{ }^{5}$ Limited evidence, in particular by Berthoud ${ }^{6}$ suggests that disadvantage may be additive so that the more disadvantages faced by an individual, the greater the likelihood of being unemployed. This is an area where more work would be useful.

\footnotetext{
${ }^{5}$ These comparisons look at a base case lone parent who is white and non-DDA disabled.

${ }^{6}$ Berthoud R 'Multiple disadvantage in employment: A quantitative analysis' Joseph Rowntree Foundation 2003
} 


\section{Most people with low skills or no qualifications face other}

disadvantages or barriers to work. Of the 4.6 million people with no qualifications, 3.5 million fall into at least one of the other DWP PSA target groups (i.e. they are disabled, aged 50 or over, a lone parent, from an ethnic minority $)^{7}$. The impact of disadvantages on employment chances is less for those who are better qualified, so improving qualification level may be a useful step for such people in the process of entering or re-entering the labour market.

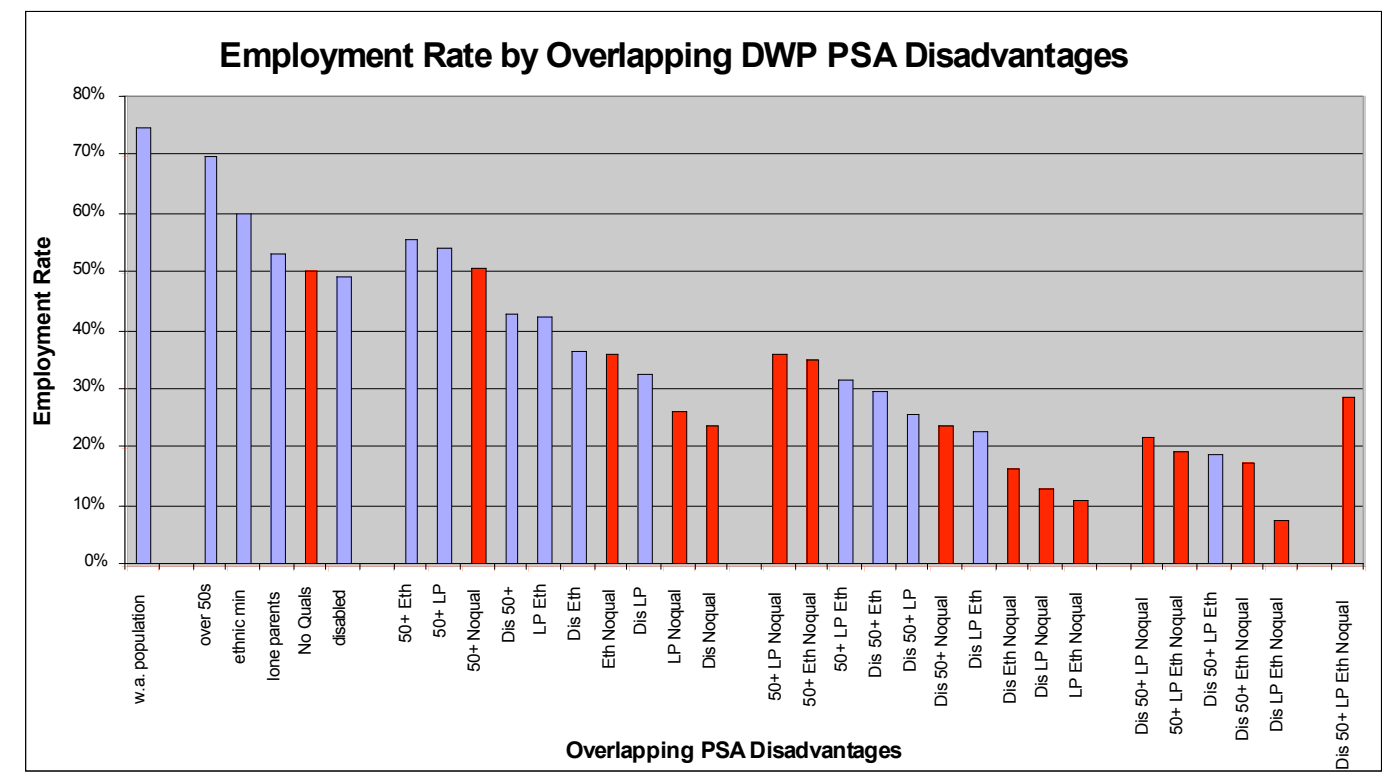

Figure 4, Source: Labour Force Survey

\section{There are many jobs that do not necessarily require formal} qualifications, but they often require skills. For example, Jackson et $\mathrm{al}^{8}$ analysed over 5000 job adverts and found that qualifications were only required in $28 \%$ of the jobs advertised. The Work Skills for Britain ${ }^{9}$ survey suggests that, despite a fall in the proportion of jobs requiring no qualifications, there are currently about 6.5 million jobs not necessarily requiring any formal qualifications. However, specific low level qualifications

\footnotetext{
${ }^{7}$ This analysis doesn't take account of the other types of disadvantage that are not measured by the LFS e.g. homelessness, drug or alcohol abuse, ex-offenders. Estimates are that $50 \%$ of ex-offenders have no qualifications and $40 \%$ of those living in temporary accommodation. ${ }^{7}$ No figures are available on the qualification levels of benefit recipients with drug or alcohol problems.

${ }^{8}$ Education, employers and class mobility Jackson M Goldthorpe $\mathrm{J}$ and Mills $\mathrm{C}$ Research in Social Stratification and Mobility (forthcoming)

${ }^{9}$ Work Skills in Britain 1986-2001 Felstead A Gallie D Green F 2002
} 
may be valued more by employers in certain sectors, such as construction, to help employers meet regulatory requirements.

\section{For low-skilled jobs, evidence ${ }^{10}$ suggests that employers value} previous work experience and generic soft skills such as motivation, punctuality, and good communication skills. For example, the Cabinet Office's review of employer perspectives on the recruitment, retention and advancement of low-pay, low-status employers ${ }^{11}$ concluded that recruitment to low-skilled jobs was likely to be based on relatively cheap, quick, and informal recruitment methods based on personal traits such as reliability, motivation, fitness, honesty, integrity and attitude.

17. However, the National Employer Skills Survey $(2005)^{12}$ reports that $31 \%$ of hard-to-fill vacancies are due to a lack of required skills, $20 \%$ are due to a lack of interest in the job, $17 \%$ to lack of work experience and $13 \%$ to a lack of qualifications. We know individuals do much better if they are qualified; employers do want skills and they may be happy to have those skills without qualifications, but qualifications can be a good way for unskilled people to acquire the skills employers want; and in the future things will get tighter and tighter.

\footnotetext{
${ }^{10}$ Newton B Hurstfield J Miller L Page R Akroyd K 'What employers look for when recruiting the unemployed and inactive: characteristics, skills and qualifications' DWP 2005

${ }^{11}$ Employer perspectives on the recruitment, retention and advancement of low-pay, lowstatus employees Atkinson J Williams M Cabinet Office July 2003

${ }^{12}$ National Employers Skills Survey 2005: Key Findings LSC June 2006
} 


\section{Conclusion}

18. There is a wealth of evidence to suggest that skills and qualifications confer substantial advantage to individuals, the economy and society through the improved chances they provide for employment. This is likely to strengthen as the economy moves towards an ever higher skill base.

19. However, we observe a core of benefit claimants who face a range of barriers to work. Whilst providing this group with more skills is important, we also need to improve our knowledge of how to ameliorate the effects of other barriers. We do not know enough about the ways in which such barriers interact. 


\section{Section Three: Evidence on the link between skills and productivity}

20. This section presents evidence on the link between skills and productivity for the economy as a whole, not specifically for those on benefits or who are inactive. The evidence available, however, does show that the effect of increasing skills on productivity is widespread and strong.

21. At the individual level, people with higher skills tend to earn more. For example, people with Entry Level 3 literacy earn 14\% more than those with Entry Level 2 or below. People with high-level communication skills earn $8 \%$ more than similar people without such skills.

22. Once in work, the higher qualified and the higher skilled are more likely to receive training and undertake further learning. In general, the returns to higher level qualifications are substantial and generally exceed those to lower level qualifications, academic qualifications tend to be higher than vocational qualifications at the same level.

\section{There are very substantial returns (of around $20 \%$ ) to vocational} qualifications when they are designed and delivered appropriately. For example, BTEC first diploma for men or RSA first diploma for women (figure 5). Also, NVQ2 has been found to have a reasonable return when delivered in the workplace (though little or no return otherwise). ${ }^{13}$ This emphasises the importance of the current programme for vocational qualification reform, primarily through employer led Sector Skills Council qualification strategies.

\footnotetext{
${ }^{13}$ Dearden, L. McGranahan, L. Sianesi, B. (2004) "An in-depth analysis of the returns to National Vocational Qualifications Obtained at Level 2", Institute of Fiscal Studies
} 


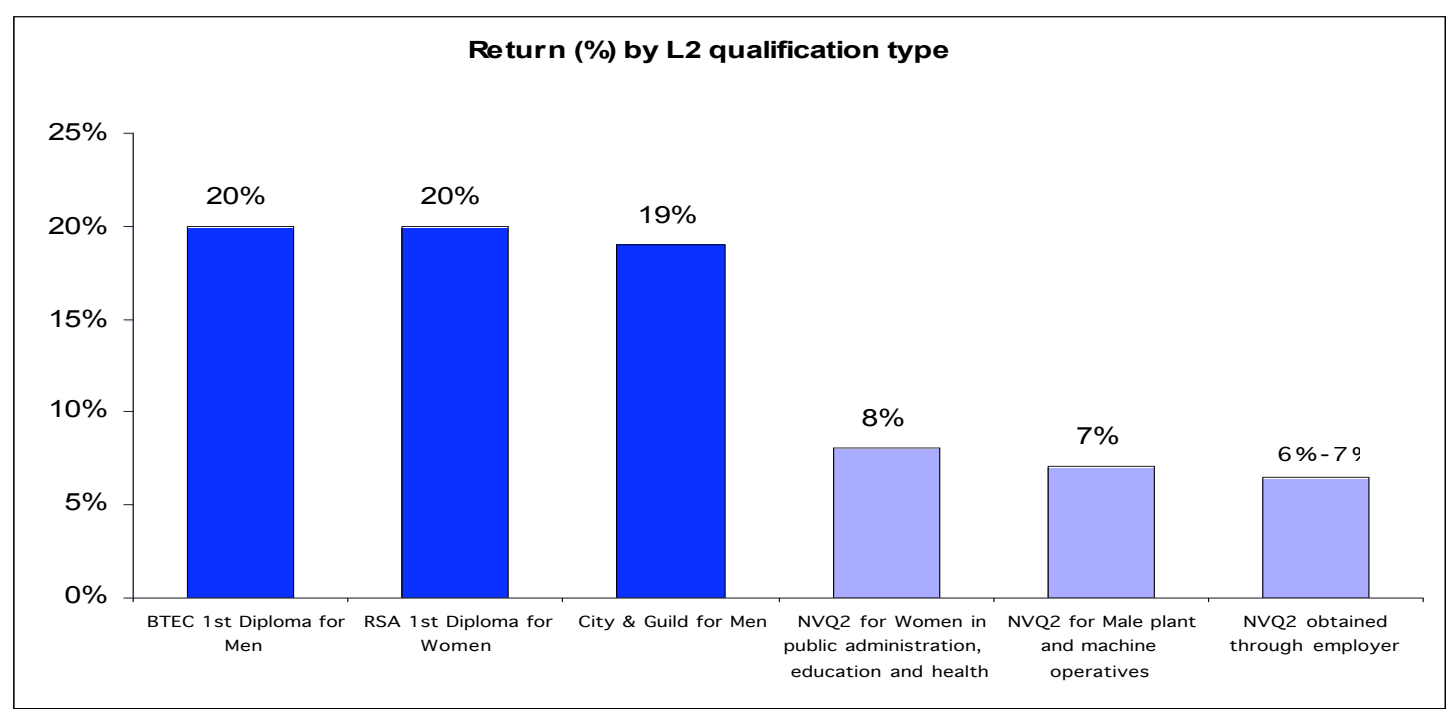

Figure 5: Wage returns for L2 qualifications. Source: L2 vocational returns: Dearden, $L$., McGranahan, M. and Sianesi, B. (2004) 'An In-depth Analysis of the Returns to National Qualifications Obtained at Level 2', CEE Discussion Paper No 46.

24. At the industry level, Dearden, Reed and Van Reenen argue that the full benefits of training are "economically large". They calculated that raising the proportion of workers trained in an industry by 5 percentage points was associated with a 4 per cent increase in value added per worker and a 1.6 per cent increase in wages $^{14}$.

\section{Skills shortages can often act as a barrier to the take up of new}

technologies and innovations. For example, research has shown that a 10 percentage point increase in the number of firms reporting skilled labour shortages in an industry will lead to a permanent $10 \%$ reduction in its fixed capital investment and a temporary $4 \%$ reduction in its R\&D expenditure. ${ }^{15}$

26. At the macro-economic level, $12 \%$ of the UK's productivity gap with France, and up to one-fifth of the gap with Germany, is due to the UK's relatively low skills level. ${ }^{16}$ Much of this is due to the relative lack of

\footnotetext{
${ }^{14}$ Dearden, L, Reed, H and Van Reenen, J (2000) Who Gains when Workers Train? Training and Corporate Productivity in a panel of British industries The Institute for Fiscal Studies, working paper $00 / 04$

${ }^{15}$ Nickel and Nicolitsas (1997) Human Capital, Investment and Innovation: What are the connections? IES University of Oxford

${ }^{16}$ O'Mahony, M. and de Boer, W. (2002) "Britain's relative productivity performance updates to 1999." NIESR
} 
intermediate vocational skills, for example the UK is ranked $20^{\text {th }}$ across the 30 countries of the OECD for intermediate skills. ${ }^{17}$

27. NIESR's 'matched plant' studies comparing UK businesses with similar firms in competitor countries found that higher average levels of labour productivity in continental Europe were closely related to greater skills and knowledge of their workforces ${ }^{18}$.

28. Sianesi and Van Reenen's (2003) ${ }^{19}$ review of the macro-economic returns to education concludes that there is compelling evidence that at the macro-economic level, human capital increases productivity. A recent paper ${ }^{20}$ found that if a country's literacy scores rise by $1 \%$ relative to the international average, we can eventually expect to see a $2.5 \%$ relative rise in labour productivity, and a $1.5 \%$ rise in GDP per head.

\section{Conclusion}

29. Skills are a key driver of productivity and are important to individuals, firms and the macro economy. Skills benefit individuals through increased probability of being in employment and higher wages; individuals with higher levels of qualification tend to earn more. Firms and employers benefit from having a more highly skilled workforce through spillover effects and increases in output and labour productivity.

30. For vocational qualifications to support the drive toward a higher skilled workforce and to compete better with other countries it is important for qualification design and delivery to focus on how to promote productivity in the long run. The next chapter focuses on how to improve the life chances of the lowest qualified and the role of skills in achieving this.

\footnotetext{
${ }^{17}$ OECD (2005) Education at a Glance.

${ }^{18}$ Haskell, J. and Pereira, S. (2002) "Skills and productivity in the UK using matched firm and worker data." ONS/DTI Productivity Workshop.

${ }^{19}$ Sianesi, B. and Van Reenen, J. (2003) "The Returns to Education: Macroeconomics." Journal of Economic Surveys Vol 17, No. 2.

${ }^{20}$ Serge Coulombe, FrançoisTremblay, and Sylvie Marchand (2004) "Literacy scores, human capitaland growth across fourteen OECD countries" Statistics Canada
} 
Section Four: Improving employment and skills levels of those with no

\section{or low qualifications or skill}

31. A challenge for government, and for DWP and DfES in particular, is to upskill the low qualified and low skilled so that they are able to move into work and be more productive in work.

32. There are $\mathbf{4 . 6}$ million people of working age without qualifications of whom 2.2 million are ILO inactive and 280,000 are ILO ${ }^{21}$ unemployed. In total there are 6.1 million people with qualifications below level 2 of whom 2.4 million are ILO inactive and 400,000 are unemployed.

33. However these average figures mask much dynamic behaviour. We estimate that 1 million low qualified people flow onto Jobseeker's Allowance (JSA) every year, of whom about 400,000 off-flow within the first 13 weeks of their claim (without Job Centre Plus (JCP) intervention). Each year around 470,000 low-skilled people move from economic inactivity into employment. The remaining 1.9 million are inactive for longer. Within three months of getting a job, $21 \%$ of people return to benefit, and early returns to benefit are associated with a lack of qualifications. ${ }^{22}$

34. Around 2.5 million people cycle on and off JSA per year. Two thirds of all JSA claims are made by people who have claimed before ${ }^{23}$. Of these repeat claimants, $23 \%$ have no qualifications, and $17 \%$ report literacy or numeracy problems. Although this is considerably higher than the proportion of the working age population without qualifications $(13 \%)$, it is slightly lower than the proportion of people claiming unemployment-related benefits without qualifications $(26 \%)^{24}$.

\footnotetext{
${ }^{21}$ The International Labor Organisation defines unemployment as those out of work, available for work and seeking work.

${ }^{22}$ Ashworth and Liu (2001) "Job seekers Allowance: transitions to work and early returns to job seekers allowance." DWP Research Report

${ }_{23}^{3}$ 'Repeat JSA Spells' DWP Research Report (2006)

${ }^{24}$ Labour Force Survey (LFS), Winter 2005. People who report claiming unemploymentrelated benefits will not include Lone Parents or Sick and Disabled people who do not claim JSA.
} 
35. Repeat claimants without qualifications or with literacy and numeracy problems are more likely to face a range of disadvantages in moving into jobs. They are more likely to move into unskilled, temporary jobs; have difficulty finding sustainable employment; be pessimistic about finding work; report difficulties in finding work because of a lack of references; apply for fewer jobs; have an indifferent attitude toward work; believe finding work is due to luck rather than effort; believe that benefits provide a more stable income than trying to earn a wage; have limited recent work experience; and face multiple barriers to work (such as health problems).

36. People with qualifications are more likely to have stable work backgrounds. Repeat claimants with only two JSA claims, who have qualifications and a history of sustainable employment, are more likely to obtain sustainable employment ${ }^{25}$.

37. However, modelling shows that qualifications held do not significantly influence the chances of an early return, all other things being equal. ${ }^{26}$

Therefore repeat claimants without qualifications may face greater barriers to finding sustainable employment than those with qualifications, but a lack of qualifications does not necessarily cause repeat spells.

38. Evidence to date suggests that tools used by Jobcentre Plus to assess skills needs have had limited success. The only skills screening that is currently carried out is for basic skills needs. $14 \%$ of JSA claimants have a basic skills need with a further $3 \%$ with an $\mathrm{ESOL}^{27}$ need.

39. For the rest of this section we summarise the evidence around how to: improve employment prospects for those with low or no qualifications a) via employment \& training programmes and b) via adult learning programmes in terms of:

\footnotetext{
25 'Repeat JSA Spells' DWP Research Report (2006)

${ }^{26}$ Ashworth and Liu (2001) 'Jobseekers Allowance: Transitions to work and early returns to JSA'

${ }^{27}$ For those whose first language is not English
} 
i) employment potential; and

ii) sustainable employment and progression in employment.

c) improve workforce skills for those with low or no qualifications once they are in work? 
Section Four part (a): What does the evidence say about how to improve employment prospects for those with low or no qualifications through employment and training programmes?

i) Employment potential

40. Despite the impact of skills on the employment prospects for the working age population, the evidence about whether they help unemployed and inactive unqualified adults to move into work is mixed. There are still a number of gaps in the evidence on what training works best and it is an open question as to whether better designed training would deliver the longer-term benefits that learning carried out at the 'usual' time provides. We need to improve our understanding of when, and how, training programmes and adult learning can improve employment prospects, and for whom they are most effective.

UK evidence

41. Some training programmes for the unemployed have had a positive impact on employment chances. The evaluation of Training for Work $(\mathrm{TfW})^{\mathbf{2 8}}$ found that participants were more likely than non-participants to move into employment, increasing the chances of employment by as much as 10-15 percentage points. Over a 17 month period after leaving TfW, participants spent an extra 1 month in 7 in work, on average, compared to what would have been expected had they not gone on the programme ${ }^{29}$. But in contrast to other programmes, there appeared to be little positive impact on employment from job search training or help with job search. The most effective strand of TfW was trainees on employer placements followed by full-time off-the-job training followed by training on project placements.

42. Internal DfES analysis suggests that the average rate of return for TfW was significantly in excess of the Treasury's 3.5\% minimum threshold for investments.

\footnotetext{
${ }^{28}$ Work based training and job prospects for the unemployed: An evaluation of training for work DfEE 1999

${ }^{29}$ Payne, J. Payne, C. Lissenburgh, S. and Range, M. Work-Based Training and Job

Prospects for the Unemployed: An Evaluation of Training for Work DfEE 1999
} 
43. Employment Training (ET) also had a positive impact on employment chances. Individuals leaving the programme spent around $5 \%$ more of their time in employment in a 15 month period than the comparison group members who did not participate ${ }^{30}$. Furthermore people on ET which included work experience ${ }^{31}$ were more likely to be in employment after the intervention.

44. The initial evaluation of Work-Based Learning for Adults (WBLA) ${ }^{32}$ found that only one of the options (Longer Occupational Training- LOT) had a positive impact on employment for JSA claimants. LOT increased the probability of working full-time by seven percentage points compared to a matched group of non-participants. The other two options included in the evaluation - Short Job-Focused Training and Basic Employability Training did not have a net positive impact on employment outcomes.

45. There are examples of employment-focussed programmes generate significant employment impacts for participants. For example the evaluation of the New Deal for Young People (NDYP) found that just over half of leavers from the Employment Option enter employment compared with 33\% from education and training ${ }^{33}$.

46. DWP has commissioned a systematic review of the evidence around the impact of adult learning on employment chances to enhance our understanding. Early findings from this review indicate that the most effective provision is a package of support involving work experience or labour market contact, individually tailored and geared towards local opportunities.

\footnotetext{
${ }^{30}$ Payne, J. Lissenburgh, S. White, M. and Payne, C. Employment Training and Employment Action: An Evaluation by the matched comparison group method DfEE 1996

${ }^{31}$ Hales and Stratford "Employment Training and Employment Action Comparison Group Study- an introduction to the study's main findings" (1995) Produced by Social and Community Planning Research (SCPR) Clemens and Gray "Employment training: a survey of ex-participants, report on phases 1 and 2." (1992) SCPR Lynn "Employment training: 1991 Survey of trainees." (1992) SCPR

${ }^{32}$ Work-based learning for adults:an evaluation of labour market effects DWP 2004

${ }^{33}$ Strategy for the unemployed: an update of the evidence DWP Internal paper October 2004
} 


\section{Past training programmes for those out of work have been} variable in quality and this may explain their limited success at moving people into jobs. If we refer people to poor quality, inappropriate training, they are unlikely to benefit from it. For example, the latest data from the Adult Learning Inspectorate (2004-5) show that the proportion of Jobcentre Plus providers rated as unsatisfactory or worse was around $40 \%$. We therefore need to build on and develop the best aspects of past programmes.

\section{It is important to take account of the longer-term impact of training} programmes. Dyke et $\mathrm{al}^{34}$ argue that it is necessary to track outcomes over an extended period of over 3 years. They concluded that intensive training is associated with earnings losses initially but greater earnings gain in the long run.

49. Analysis ${ }^{35}$ of the longer-term effects of the different New Deal for Young People options showed that the employment outcomes over a four year period, for those participating in Full Time Education and Training (FTET) had improved, and they spent longer in employment than those taking part in the Voluntary or Environmental Task Force Options. However, it is worth noting that someone who took part in FTET was likely to spend $10.8 \%$ less time in employment than someone who took the Employment Option.

50. DWP commissioned a study ${ }^{36}$ to look at the longer term impact of WBLA. This study looked at employment outcomes over a three year period. It found that for the Short Job-focussed Training Option employment outcomes were 5 percentage points higher than those for a control group. Similarly, the outcomes for participants on Longer Occupational Training were 5 percentage points higher than the control group and for Basic Employability Training, a difference of 5 percentage points. However, it should be noted that positive outcomes of this scale are not cost effective given the budget spent on WBLA.

\footnotetext{
${ }^{34}$ The effects of welfare-to-work program activities on Labour Market Outcomes Dyke A Heinrich C Mueser P Troske K Institute for Research on Poverty March 2005

${ }^{35}$ The longer term impact of the New Deal for Young People Beale et al DWP in-house paper

${ }^{36}$ The longer term outcomes of Work-Based Learning for Adults: Evidence from Administrative Data' Speckesser Stefan Bewley Helen DWP (forthcoming)
} 
51. US evaluation evidence finds that employment-focused programmes generally have larger effects on employment and move people into jobs more quickly than education-focused programmes ${ }^{37}$ Whilst the US evidence is not directly comparable to the UK experience, the quality of the methodology of the evaluations and robustness of the results, gives some merit to discussing the literature.

52. An evaluation of 11 US welfare-to-work strategies showed the employment focussed approach to be more successful than the training first approach in moving people into work ${ }^{38}$. Contrary to expectation, the training first approach did not consistently result in boosting earnings of participants, or in increasing the likelihood of having a 'good' job (i.e. a job that is stable and well-paying).

53. A further study by Greenberg et $\mathrm{al}^{39}$ looked at data from 64 US welfareto-work programmes and concluded that 'employment focused' programmes initially had a stronger effect on employment outcomes than training programmes, but this effect declined more rapidly than the impact of training programmes once the maximum effect was reached. However, this could be because the 'training' programmes included in the study only provided very short-term training.

54. The most successful US programme (Portland, Oregon) involved a mixture of both approaches where less job-ready people were sent on training and the others were assigned to job search activities. ${ }^{40}$ This programme raised participants earnings by $35 \%$ after two years and increased their

\footnotetext{
${ }^{37}$ Moving People from Welfare to Work Lessons from the National Evaluation of Welfare-toWork Strategies US Department of Health and Human Services and US Department of Education July 2002. It is important to note that after a period of time, work-focused programmes tend to offer short-term training to those who are unsuccessful in finding a job.

${ }_{38}$ The US evidence almost solely pertains to lone parents (usually women) whose participation on programmes is mandatory.

${ }_{39}$ Do welfare to work programmes work for long? Greenberg et al (2004) Fiscal Studies vol. 25 , no.1

40 "Moving people from Welfare to Work: Lessons from the National Evaluations of Welfare-toWork strategies" Hamilton Gayle U.S Department of Health and Human Services U.S Department of Education July 2002
} 
employment chances by 11 percentage points, key features of this programme included:

○ a strong employer focus;

o the use of both job search and short-term education and training;

- provision of high quality services;

○ integrated case managers responsible for welfare eligibility;

○ an individualised work experience component; and

- specifically and uniquely, participants were counselled to hold out for a good job, one which paid at least $25 \%$ above the minimum wage and offered a good chance for stable employment ${ }^{41}$.

55. Evidence from West Germany finds that intensive training programmes can deliver long term employability benefits. For example, one study found that over seven years the most intensive retraining programme had the best employment outcomes ${ }^{42}$. Although there were no positive effects on employment in the short-term, those receiving re-training were between ten and fifteen percentage points more likely to be in employment seven years after starting the programme when compared with a control group. It should be noted that those taking part on the programmes in Germany tended to be short-term unemployed with some skills and previous work experience.

ii) Sustainable employment and progression in employment.

56. One of the reasons for upskilling people with no or low qualifications is to improve sustainability in employment and to enable career progression.

57. The limited available evidence suggests that training programmes for the unemployed have generally had little success in raising the hourly earnings of participants once in work. For example, the evaluation of Work Based Learning for Adults (WBLA) found that Longer Occupational Training (LOT) had no impact on earnings, although LOT did increase the number of

\footnotetext{
${ }^{41}$ It should be noted that Portland's caseload were predominantly white, a high proportion had qualifications and the programme operated at a time when Portland's economy was buoyant. 42 It should be noted that those taking part on the programmes in Germany tended to be short-term unemployed with some skills and previous work experience.
} 
hours worked. Short-Job-Focused Training in WBLA raised the chances of being employed five months after enrolling by 5-7 percentage points, but this impact wasn't sustained (except for the over $50 \mathrm{~s})^{43}$.

58. Similarly, the evaluation of TfW found no impact on hourly wage rates for participants. However by increasing the chances of full-time rather than a part-time job, participation in the programme did improve take-home pay.

Section Four part (b): What does the evidence say about how to improve employment prospects for those with low or no qualifications through adult learning?

i) Employment potential

59. As well as the evidence on government training programmes, evidence from adult learning (all learning undertaken by adults, including college-based learning) suggests that attaining Level 2 vocational qualifications significantly enhances the employment prospects of unqualified school leavers. Evidence in this area tends to focus on the working age population, rather than those who are unqualified and out of work; so our knowledge of the effects of adult learning for these individuals is relatively limited.

60. McIntosh (2004) found that unqualified male school leavers who go on to obtain Level 2 vocational qualifications are 10 percentage points more likely to be employed than those who do not acquire any qualifications after school. This is a higher employment rate (89\%) than those who leave school with $5+$ GCSEs $A^{*}-C$ but achieve no further qualifications $(88 \%)$. For unqualified female school leavers, the impact of Level 2 vocational qualifications is even higher at 19 percentage points. ${ }^{44}$ This significantly reduces the employment gap relative to those who leave school with 5+ GCSEs $A^{*}-C$ but achieve no further qualifications.

\footnotetext{
${ }^{43}$ Work-based learning for adults:an evaluation of labour market effects DWP 2004

${ }^{44}$ McIntosh, S. (2004) 'The Impact of Vocational Qualifications on the Labour Market Outcomes of Low-Achieving School-Leavers', CEP Discussion Paper No 621.
} 
61. Jenkins et $\mathrm{al}^{45}$ (2002) found that women who were unemployed and gained low-level qualifications were significantly more likely to move into work than women who did not gain qualifications or take part in learning. However, it tended to be women who already possessed qualifications that undertook further learning.

\section{ii) Sustainable employment and progression in employment.}

62. Adult learning typically has limited impact on earnings, but there is some evidence that it might raise earnings of particular groups. Furthermore, attainment of Level 2 vocational qualifications for unqualified school leavers raises the probability of individuals moving up the occupational hierarchy by 1.4 percentage points. Given that on average only $4 \%$ of the overall sample report such a movement up the occupational hierarchy, this represents a substantial effect for those that do move. However, Jenkins (2004) found that although adult learning improved the employment chances of women, it did not have a significant impact on their earnings.

Section Four part (c): What does the evidence say about how to improve workforce skills for those with low or no qualifications once they are in work?

63. Workplace learning generally has a consistent, and significantly positive, impact on earnings and productivity - more so than adult learning or government provided training programmes. For example, Blundell et al $(1996)^{46}$ found that a spell of employer provided training yielded a pay-off of around $5 \%$ to individuals' real earnings growth (for individuals aged between 23 and 33). Similarly, the returns to NVQ 2s are much higher for those who gain their NVQ via an employer. ${ }^{47}$ If we are to close the skills and productivity gaps with our key competitors, we need to ensure that

\footnotetext{
45 Jenkins A 'Women, Lifelong learning and employment' CEE August 2004

${ }^{46}$ Blundell, R. Dearden, L and Meghir, C. The Determinants of Work-Related Training in Britain (1996) IFS

${ }^{47} \mathrm{An}$ in-depth analysis of the returns to National Vocational Qualifications Obtained at Level 2 Dearden L McGranahan L Sianesi B IFS 2004
} 
unqualified and low-skilled individuals, when in work, have the opportunity to improve their skills.

64. Training in the workplace leads to employment stability. Blundell et al found that average job tenure for someone who had received employerprovided training in their current job was 9.5 years for men and 8.9 years for women, and was significantly higher than for those who had not received employer-provided training (6.8 years for men and 5.1 years for women).

\section{NALS ${ }^{48}$ shows that participation in learning is greatest for those in} work, $(89 \%$ of those in full-time work have done some learning in the last 3 years), lower for the unemployed (68\%), and lower still amongst those looking after the family (52\%) and those incapable of work (42\%). ${ }^{49}$ People who engage in learning are more likely to engage in further learning (see figure 6).

\section{Future learning intentions of adults by highest}

\section{qualification}

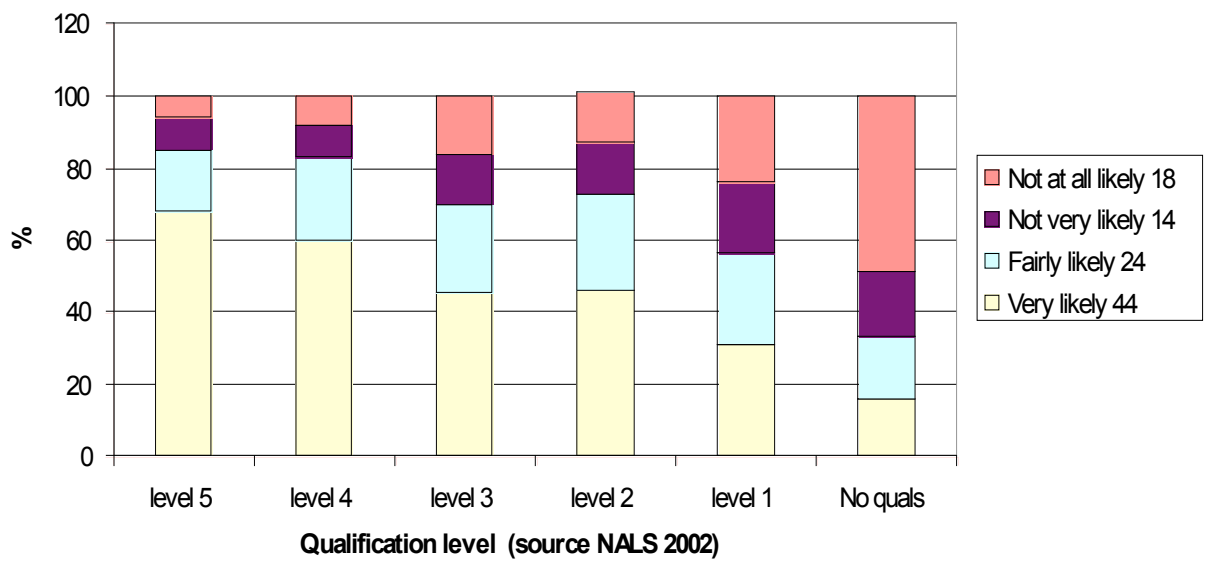

Figure 6: Those with qualifications at level 2 and above are more likely to report that they have future learning intentions.

66. However, the receipt of workplace learning is heavily skewed towards those with qualifications above level 2, see figure 7. For example, only $5.1 \%$ of people with no qualifications received training in the past 4

\footnotetext{
${ }^{48}$ National Adult Literacy Survey.

${ }^{49}$ National Adult Learning Survey (NALS) DfES RR 3212001
} 
weeks, compared to $15 \%$ of people with Level 2 qualifications. ${ }^{50}$ The British Household Panel Survey (BHPS) shows that $70 \%$ of unqualified people had not received training at work in the previous five years. The types of occupations that unemployed unqualified people tend to enter (elementary occupations and plant and machine operative occupations) are also associated with the lowest incidence of training. So, many low skilled people are not improving their skills whilst out of work or once in work

Percentage of employees receiving training in the last 13 weeks by highest qualification

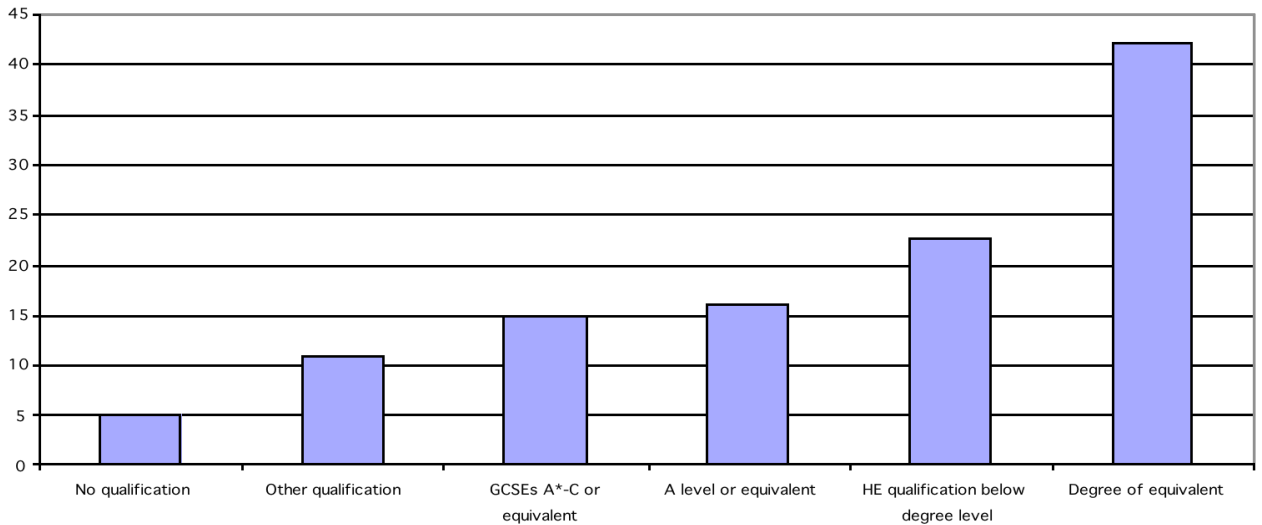

Figure 7, Source: LFS Spring Quarters 2005 (taken from Education and Training Statistics)

67. Feinstein et al (2004) $)^{51}$ also found consistently good returns for those who receive workplace training. However, the people that employers chose to train were those who already had qualifications.

68. We cannot rely on employers to invest in the skills of the lowest skilled without some form of government intervention as there is a market failure, most likely because employers cannot be sure the individual has the ability or motivation to benefit from training. Therefore, this suggests a role for government in ensuring workers have a minimal level of competency, so employers are willing to invest in workforce skills at higher levels of learning. This basic level of competence would seem to be a level 2 , as after this threshold, the chances of an individual receiving employer provided training increases.

\footnotetext{
${ }^{50}$ OECD (2005) Education at a Glance, pp72.

${ }^{51}$ Feinstein, Galindo-Rueda and Vignoles (2004) "The Labour market Impact of Adult Education and Training: A Cohort Analysis." CEE paper
} 


\section{There is a significant policy challenge for Government to}

\section{encourage training for unqualified people in work and promote}

additionality. Here, Train to Gain will play an important role in enabling the unqualified group to develop and progress into more sustainable, productive employment over time. The Year 2 evaluation of the Employer Training Pilots $(E T P)^{52}$ - a forerunner to Train to Gain - found that $77 \%$ of employers agreed that ETP provided an opportunity for them to train employees who they would not otherwise have trained. However, estimates suggest that $85-90 \%$ of employers who participated in the pilots would have paid for training in the absence of the programme..$^{53}$ In addition, a substantial proportion of those undertaking training through the ETP pilots would have done so in the absence of ETP.

\section{Conclusions}

70. To date, there have been two main approaches in improving the labour market chances of low skilled people, through employment focused or education focused programmes. The general findings from the evidence suggest that:

- employment focused programmes are generally more effective in getting individuals into the labour market in the short-term;

- In the longer-term, UK evidence shows examples where employment focused and training focused programmes have had positive impacts on employment. Internationally, there is evidence to suggest that training programmes have better long-term outcomes on employment chances than the short term outcomes suggest;

- long term impacts of training programmes on earnings are mixed;

\footnotetext{
${ }^{52}$ Platform for progression: Employer Training Pilots Year 2 evaluation report Hillage $\mathrm{J}$ Lukas G Newton B Tamkin P DfES March 2005

${ }^{53}$ The Impact of the Employer Training Pilots on the Take-up of Training Among Employers and Employees Abramovsky Battistin Fitzsimons Goodman Simpson, IFS, DfES Research Report 694, 2005
} 
- Evidence, including international evidence, suggests that the most effective way to improve the labour market outcomes of low-skilled people is a combined approach, where people continue active job search and undertake training which is continued once they enter employment.

- Adult learning tends to have good impacts on employment, although it is difficult to isolate the target group.

71. For low-skilled individuals in the workplace, the evidence suggests that the best improvement in earnings and productivity occurs when qualifications are gained in the workplace. However, the evidence is clear that low-qualified and low-skilled people are much less likely to receive training from their employers. 


\section{Section Five part (a): The future supply of skills}

\section{There have been major changes in the structure of UK}

employment over the past $\mathbf{5 0}$ years. These have been caused by a myriad of interdependent factors which have impacted upon the shape of the labour market and the demand for skills at various levels. These factors include: technological change; productivity growth; and globalisation.

73. The world economy is becoming more competitive and open. In particular, countries such as China and India are able to produce goods and services at lower costs, and some work is being transferred from the UK to those countries. We need to develop a comparative advantage in new markets with higher value-added, but to do this we need to improve the supply of skills at all levels.

Recent trends

\section{There has been a consistent pattern of increasing skills supply in} recent years according to most measures. Figure 8 below shows progress on such trends. In particular, the number of people with no qualifications or qualifications below level 2 fell from 14.6 million to 11.8 million between 1994 and 2004. In the same period the number of people at degree level rose by 3 million.

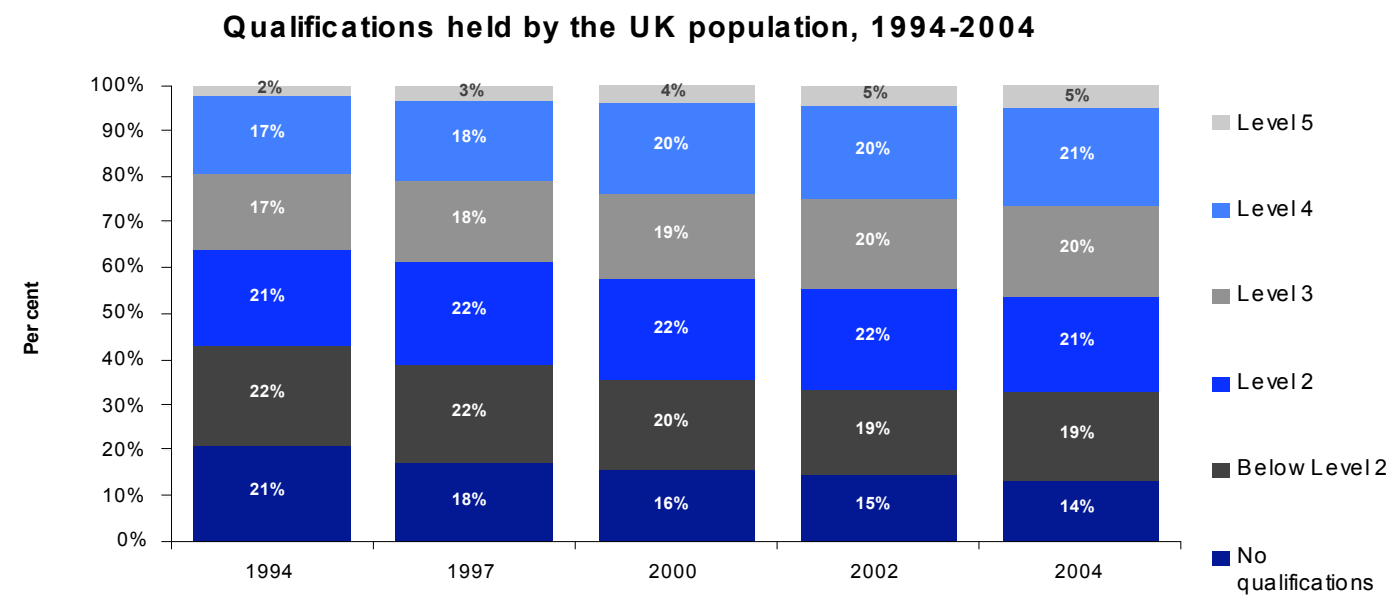

Source: Labour Force Survey, autumn quarters Base: UK working age population

Figure 8: The trend for increasing qualifications in the UK working age population between 1994 and 2004. Source: Leitch Review of Skills Interim Report (2005) 
75. Despite upskilling, returns have remained stable over time. The chart below (figure 9) shows the earnings differential between those qualified to level 2 and above and those qualified to below level 2. Despite the increase in the proportion of the workforce holding qualifications at Level 2 or higher (35\% in 1994 to $44 \%$ in 2002 = lower line, right-hand axis), the earnings differential has, despite some fluctuation, increased from $+£ 2.66 /$ hour in 1994 to $+£ 3.00$ /hour in 2002 (upper line, left hand axis). This suggests that there is unmet demand in the labour market for these more highly qualified workers. As wages partly reflect workers' productivity, continued improvements in skill levels are contributing to productivity improvements (as measured by wages).

Earnings differential between level 2+ and below level 2 over time

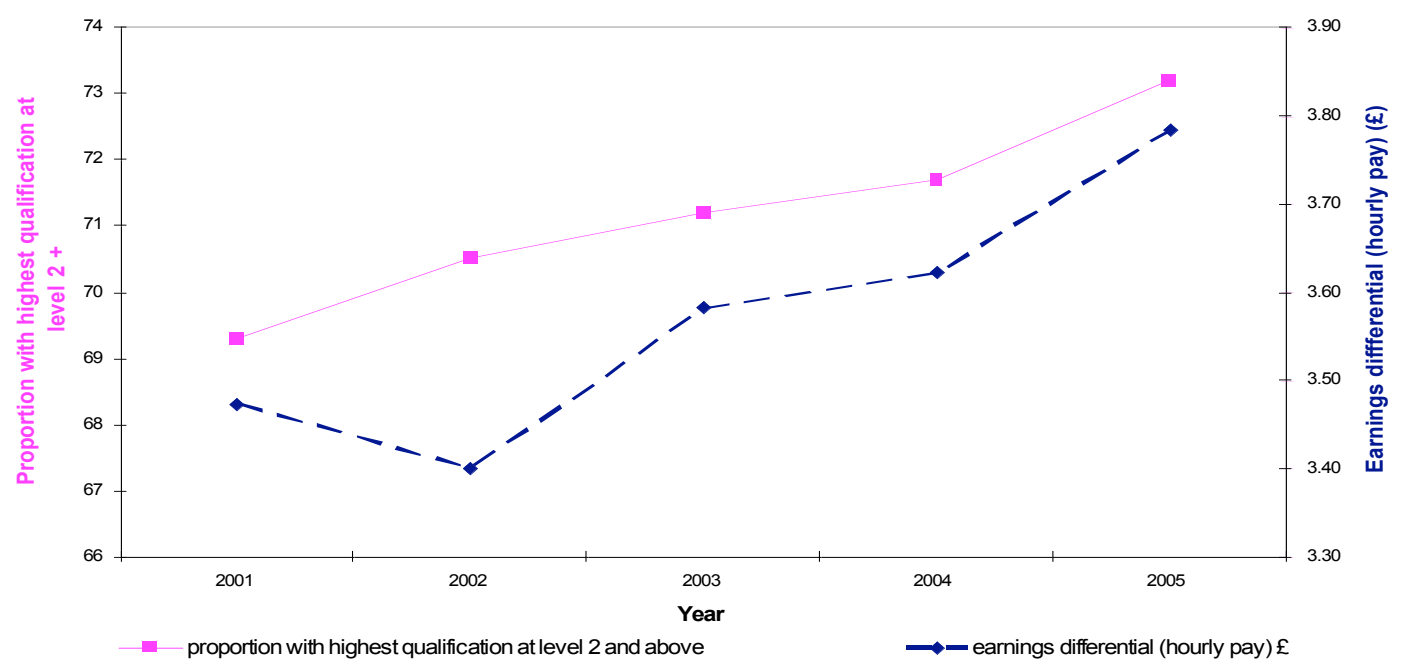

Figure 9: Wage differentials for those with higher qualifications have persisted over time.

\section{Future Projections}

76. The Leitch Review of Skills estimates that if the government meets its current targets for improving skills, and current trend persist then the proportion of working age people without any formal qualifications will fall from $13 \%$ in 2005 to $4 \%$ in $\mathbf{2 0 2 0}$. This means there will be 1.5 million individuals without qualifications in the 2020 working age population, 3.6 million fewer than in 2005. 
77. The Leitch review team modelled current ambitions as a baseline and looked at three options for raising our ambitions to 2020. These included tackling adult basic skills and low level skills at level 2. All scenarios exhibit significant economic and social benefits; and the scenario modelling the attainment of low level qualifications for 3.5 million adults by 2020 would have the most significant impact on reducing inequality. The benefits estimated were that:

- it would increase output per worker by 3.2 per cent over the baseline projection (i.e. if targets are met and trends continue);

- the employment level would be 375-425,000 higher in 2020 (which represents an increase in the employment rate of 0.9-1.1 percentage points);

- net benefits over the period could amount to £85-105 billion;

- with a total additional cost of only $£ 1.5$ billion.

- the wider benefits are likely to be higher when tackling low skills $^{54}$

78. If we improve the basic skills of the adult population faster than under current ambitions, ${ }^{55}$ this would decrease below level 1 literacy and numeracy needs by 2.7 million and 2.4 million respectively. This would cost $£ 800$ million but would have a net benefit of $£ 50-70$ billion over the period. It would increase the employment rate moderately by $0.15-0.25$ percentage points and output per worker would be $0.47 \%$ higher in 2020 . The findings of this review highlight the huge potential economic gains from increasing our skills level.

\footnotetext{
${ }^{54}$ Since the benefits in terms of health; crime and social cohesion are usually found at the bottom and top end of the skills distribution.

${ }^{55}$ With a two and a half fold increase in the attainment rate of basic skills over and above current ambitions (relating to the Basic Skills PSA target.)
} 


\section{Section Five part (b): The future demand for skills}

79. Projections of the future occupational structure of the UK to 2020, commissioned for the Leitch review, ${ }^{56}$ show that employment levels in higher occupational groups ${ }^{57}$ such as managers and senior officials, professional and associate professional and technical occupations are set to increase. IER projects that the share of overall employment in these occupations will rise from $41.4 \%$ to $46.4 \%$, a growth of over 2.5 million new jobs.

80. Employment levels in lower skilled professions such as elementary and machine and transport operatives are set to decrease by 978,000 in the same period. However, this masks a more complex picture for this occupational group with some machine and transport operative occupations projected to experience modest increases.

81. The trend in the middle ranking occupations is not as clear. A reduction in employment levels for administrative and secretarial and skilled trade occupations of 533,000 is forecast. Whilst there are projected to be increasing employment levels for personal service and sales and customer service occupations of almost 1.2 million between 2004 and 2020.

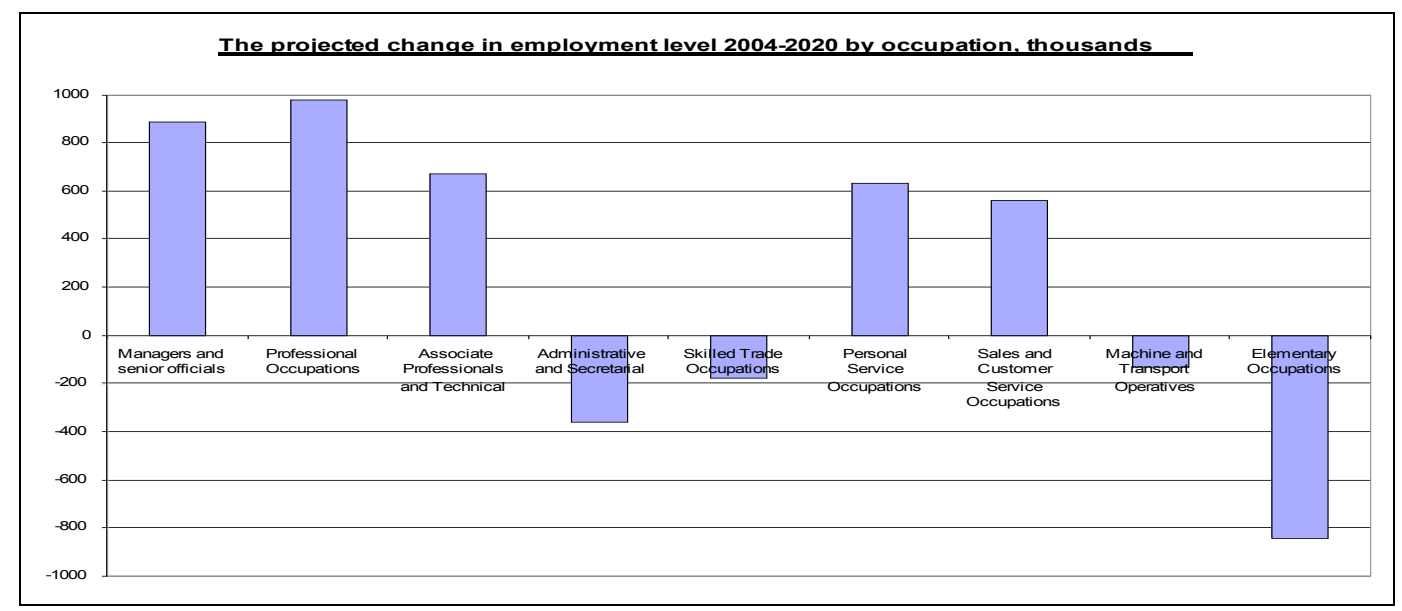

Figure 10: Changes in employment levels by occupation between 2004 and 2020. Source: Leitch Review of Skills Interim Report (2005) CE/IER employment projections

\footnotetext{
${ }^{56}$ There are also more detailed but less forward looking Working Futures projections which look to 2014, but these generally show the same picture as those produced for the Leitch Review.

${ }^{57}$ Which are typically characterised by high skill requirements.
} 
82. Elementary occupations are expected to continue the declining trend in employment ${ }^{58}$. The Working Futures report attributes this change to this occupational group being hit particularly hard as a result of growth in IT services. ${ }^{59}$ This is of particular importance as estimates show that $28 \%$ of all low skilled people in employment work in elementary occupations ${ }^{60}$ and that $38 \%$ of people employed in elementary occupations are low skilled.

\section{However, the growth in the number of new jobs is only one}

\section{element of employment demand. We must also consider replacement} demand. This refers to demand for workers to fill positions that have been left vacant by previous workers, leaving mainly through retirement. IER estimate that replacement demand due to retirements, mortality, occupational mobility and migration will lead to nearly 6 million job opportunities between 2004 and 2020 in the top three occupational categories (managers, professionals and associate professionals). However, there will continue to be significant job opportunities at the lower-end of the labour market with $\mathbf{2 . 9}$ million jobs needing to be filled in elementary and transport and machine operative occupations over the same period.

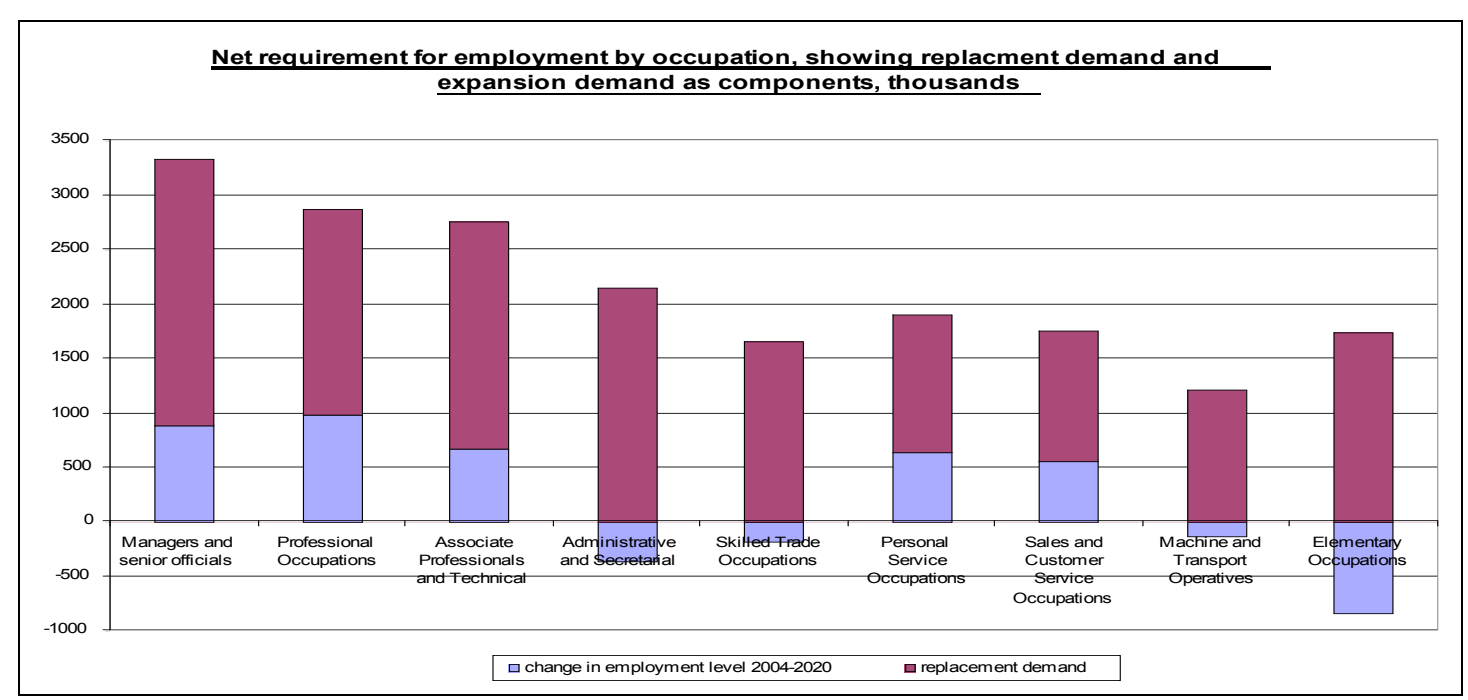

Figure 11, Source: Leitch Review Interim Report, CE/IER Employment Projections.

\footnotetext{
${ }^{58}$ This refers to the Working Futures report forecasting trends to 2014.

${ }^{59}$ SSDA, Working Futures 2004-2014, National Report, p74.

${ }^{60}$ LFS Winter 2005, where low skilled are people of working age (16-60/65) whose highest qualification is below level 2 , excluding students, retired people, and people with other or don't know qualifications.
} 


\section{Conclusion}

84. The supply of skills in the labour force has been improving over recent years and this trend is set to continue. We might reasonably seek to aim higher in our ambitions for a skilled workforce in order to enhance labour market flexibility in the face of globalisation and economic growth.

85. Some analysts, for example Goos and Manning ${ }^{60}$, have observed a polarisation or hollowing out over recent years which they attribute to technology removing machine replaceable jobs at intermediate skill levels, with low skill and high skill jobs having a greater proportion of non-machine replaceable jobs. However, the wages for low skilled jobs have declined at the same time the number of jobs has increased, so at least part of the explanation for the increase in low skill jobs could be due to changes in relative benefit levels that has led to lower wages and hence increased demand by employers. Unlike technological change, the wage effect will not be a long term trend, suggesting that while the proportion of high skill jobs is likely to continue to increase, the same is not true of low skill jobs.

86. There are conflicting views about the future labour market demand for low skilled people in the face of heightened global competition.

- Some, including the projections to inform the Leitch Review, believe the number of low skilled jobs will continue to fall significantly.

- Other analysts, for example Goos and Manning ${ }^{61}$, argue that there is a demand for low skilled jobs which could continue into the future.

\footnotetext{
${ }^{61}$ Lousy and lovely jobs: The rising polarization of work in Britain Goos M and Manning A 2003 Centre for Economic Performance
} 


\section{Section Six: Main Conclusions for Policy}

87. We can conclude from the evidence that:

- Skills and qualifications have a positive impact on an individual's employability and productivity.

- The UK has a long tail of low-skilled adults who are increasingly inactive in the labour market and this contributes to poor international productivity performance.

- The majority of people without qualifications face multiple barriers to work. $77 \%$ of people without qualifications also face another barrier.

- Many low skilled vacancies do not state the need for formal qualifications (although they often require skills or competences).

- Unqualified people tend to move into low-skilled, low productivity employment with little stability and may tend to recycle through the benefit system.

- Employment focused interventions have generally had more impact on initial employment outcomes than education focused interventions.

- However, training is good for longer term outcomes and provides opportunities for progression. Also, there are some instances where training has substantially improved employment chances.

- The most effective training programmes retain a work focus, have links with employers, and are tailored to suit individual needs.

- Returns to adult learning are generally greatest when delivered through the workplace and such learning has a sustained impact on earnings and tenure.

- Unqualified people are more concentrated in occupations with the lowest incidence of training.

- People with qualifications below level 2 are least likely to be offered employer provided training.

88. The policy challenges emerging from the evidence are:

- We need to develop better ways of identifying those for whom a lack of skills or qualifications is a barrier preventing them from moving into 
good quality, sustainable work and refer them to information and advice services or suitable training provision.

- We need to correct for the market failure which results in employers under investing in their workforce.

- We need to ensure training is well designed and delivered.

- We need to develop a seamless service so that, for example, when people start to improve their skills whilst on benefits they can continue their learning or training once they move into work.

89. Meeting these challenges will require a joined-up system of employment; benefits and skills with these suggested key features:

- employer involvement and leadership of employment and skills support

- a strong and continuous labour market focus for clients of working age; a coherent system for clients and employers, providing good customer service with a seamless and professional public face;

- a qualifications framework which better reflects where skills gained are relevant to employer needs;

- increased employer engagement and commitment to skills training, particularly for the low skilled;

- incentives, targets and performance management systems that create focus on enabling people to secure and retain productive, sustainable jobs;

- better ongoing support, for people moving into work (including support for training across the return to work boundary); and

- measures to overcome the weak engagement of the most low-skilled, including:

- better marketing to attract those who currently do not seek or find support and advice;

- active referral and management of people needing most help; and

- enhanced incentives for the least skilled and those out of work, including the wider inactive group. 


\section{Appendix A-The role of qualifications}

90. Qualifications are usually used as a proxy for skill levels, but qualifications and skills are not the same thing. Qualifications can be seen as a snapshot measure, in that they certify someone's skill level at a particular moment in time. Skills atrophy over time if they are not used. In addition, there are lots of people who have skills that are uncertified, and whose qualification level might not be a true reflection of their skills. Because of this, it can be argued that qualifications are only a crude proxy for skills.

91. However, skill levels are extremely difficult to quantify. Most skills are not directly observed and so they have to be measured by some kind of proxy. This proxy could be based on a number of factors, e.g. occupation type, highest qualification, age (as a crude proxy for work experience and some of the informal on-job training) etc. Highest qualification level is the proxy that is most commonly used as it is the best readily available measure.

92. Principally, qualifications provide much needed information in the labour market, for both individuals and employers. Employers can use qualifications to measure the quality of potential recruits at the application stage; they can measure progress of individuals throughout their lifespan. Individuals can value qualifications as they provide a badge of quality accredited by an awarding body for a particular course; this means that the provision must meet minimum standards. This enables individuals to make informed decisions about which courses to participate in to maximise the return on their investment.

93. One potentially useful role of qualifications is to act as a signal for employers by being an effective screening tool for use in recruitment when deciding which of a variety of applicants to hire. They also indicate skills progression and act as a reward for learners, although not all skill progression will be captured by qualifications, for example informal and non-formal learning done which does not lead to certification. This may lead to an 
underestimation of the skills level in the economy when using qualifications as a proxy.

94. Qualifications also open the gateway in recruitment for individuals and motivate learning and achievement. They do this by recognising achievement as well as providing evidence of progress therefore giving employees the chance to progress in the labour market. It is also used as a means of regulating quality in the provision of good and services and in some sectors may be used to ensure a quality standard by making it a requirement to hold such a qualification as a part of a license to practice.

95. Qualifications also act as a quality badge for courses as they are accredited through an awarding body, and hence ensure standards remain high. It can also be used as an evaluation tool to measure the results of learning by a common standard. It may also be used, at an individual level, as an indicator of learning needs, of learning gained and as a proxy of the skills level in the economy.

96. To perform these roles, qualifications should be transparent, portable, prepare individuals well for future employability and be esteemed by employers (who are the consumer of the product). They should also adequately portray the quality of the learning provision on offer so as to act as an information tool for individuals who are the consumer of learning provision. The current challenge for DfES is to ensure that qualifications do meet these requirements. In particular it is important to ensure that employers recognise and value lower level vocational qualifications. Current evidence suggests that employers tend to use personal attributes rather than qualifications when recruiting for low-skilled jobs. 


\section{$\underline{\text { References }}$}

Abramovsky, Battistin, Fitzsimons, Goodman and Simpson (2005) "The Impact of the Employer Training Pilots on the Take-up of Training Among Employers and Employees", IFS, DfES Research Report 694.

Anderson, Dorsett, Hales, Lissenburgh, Pires and Smeaton (2004) "Workbased learning for adults: an evaluation of labour market effects" DWP Research Report 187

Ashworth and Liu (2001) "Job seekers Allowance: transitions to work and early returns to job seekers allowance." DWP Research Report

Atkinson J Williams M (2003) "Employer perspectives on the recruitment, retention and advancement of low-pay, low-status employees" Cabinet Office

Beale et al "The longer term impact of the New Deal for Young People." DWP in-house paper

Berthoud R (2003) 'Multiple disadvantage in employment: A quantitative analysis' Joseph Rowntree Foundation

Blundell, R. Dearden, L and Meghir, C (1996) "The Determinants of WorkRelated Training in Britain" Institute for Fiscal Studies

Carpenter, H. (2006) 'Repeat JSA Spells’ DWP Research Report No. 394.

Clemens and Gray (1992) "Employment training: a survey of ex-participants, report on phases 1 and 2." SCPR

Coulombe, Tremblay, and Marchand (2004) "Literacy scores, human capital and growth across fourteen OECD countries" Statistics Canada

Dearden, Reed and Van Reenen (2000) Who Gains when Workers Train?

Training and Corporate Productivity in a panel of British industries The Institute for Fiscal Studies, working paper 00/04

Dearden, McGranahan and Sianesi (2004) 'An In-depth Analysis of the Returns to National Qualifications Obtained at Level 2', CEE Discussion Paper No 46.

DWP (2004) "Strategy for the unemployed: an update of the evidence" Internal paper.

Dyke, Heinrich, Mueser and Troske (2005) "The effects of welfare-to-work program activities on Labour Market Outcomes." Institute for Research on Poverty

Feinstein, Galindo-Rueda and Vignoles (2004) "The Labour market Impact of 
Adult Education and Training: A Cohort Analysis." CEE paper

Felstead, Gallie and Green (2002) "Work Skills in Britain 1986-2001"

Goos and Manning (2003) "Lousy and lovely jobs: The rising polarization of work in Britain." Centre for Economic Performance

Greenberg et al (2004) "Do welfare to work programmes work for long?" Fiscal Studies vol.25, no.1

Hales and Stratford (1995) "Employment Training and Employment Action Comparison Group Study- an introduction to the study's main findings" Produced by Social and Community Planning Research (SCPR)

Hamilton (2002) "Moving people from Welfare to Work: Lessons from the National Evaluations of Welfare-to-Work strategies" U.S Department of Health and Human Services U.S Department of Education.

Haskell, J. and Pereira, S. (2002) "Skills and productivity in the UK using matched firm and worker data." ONS/DTI Productivity Workshop.

Hillage Lukas Newton Tamkin (2005) "Platform for progression: Employer Training Pilots Year 2 evaluation report" DfES

Jackson M Goldthorpe J and Mills C (forthcoming) "Education, employers and class mobility" Research in Social Stratification and Mobility.

Jenkins A (2004) 'Women, Lifelong learning and employment' CEE LSC (2006) "National Employers Skills Survey 2005: Key Findings"

La Valle and Blake (2001) "National Adult Learning Survey 2001" DfES Research Report 321

Lynn(1992) "Employment training: 1991 Survey of trainees." SCPR

McIntosh, S. (2004) 'The Impact of Vocational Qualifications on the Labour Market Outcomes of Low-Achieving School-Leavers', CEP Discussion Paper No 621.

Newton B Hurstfield J Miller L Page R Akroyd K (2005) 'What employers look for when recruiting the unemployed and inactive: characteristics, skills and qualifications' DWP Research Report

Nickel and Nicolitsas (1997) Human Capital, Investment and Innovation: What are the connections? IES University of Oxford

O'Mahony and de Boer, (2002) "Britain's relative productivity performance updates to 1999." NIESR 
Payne, J. Lissenburgh, S. White, M. and Payne, C. (1996) "Employment Training and Employment Action: An Evaluation by the matched comparison group method" DfEE

Payne, J. Payne, C. Lissenburgh, S. and Range, M. (1999) "Work based training and job prospects for the unemployed: An evaluation of training for work" DfEE

Sianesi, B. and Van Reenen, J. (2003) "The Returns to Education:

Macroeconomics." Journal of Economic Surveys Vol 17, No. 2.

Speckesser and Bewley (2006) "The longer term outcomes of Work-Based Learning for Adults: Evidence from Administrative Data" DWP

Wilson, Homenidou and Dickerson (2006) "Working Futures 2004-2014", National Report", SSDA. 